\title{
A view on issues outside the farm gate that will influence the performance of hill country farming
}

\author{
G.T. HARRISON \\ ANZCO Foods Limited, PO Box 39145, Harewood, Christchurch 8545, New Zealand \\ Graeme.Harrison@anzcofoods.com
}

Thank you for the invitation to be with you today and to participate in this symposium.

As a recent newcomer to the ranks of hill country farming, I am looking forward to picking up some pointers I can take back to my small team at Mt Alford Station in Mid Canterbury.

With academics and commentators speaking out strongly against the Trans Pacific Partnership (TPP), central Auckland traffic being brought to a standstill by protests around the signing of TPP on 4 February, global dairy prices slumping, and major daily fluctuations seemingly becoming normal in global stock markets, you could be forgiven for concluding that nothing is rational or normal anymore.

I was in Tokyo during the Chinese New Year the week after TPP was signed. Never have I seen so many foreign tourists in that city, especially from China, spending up large. Japan, after being a net deficit country in travel continuously from 1962 to 2014, is now a major beneficiary of inward tourism. The rise of Asia's growing middle class is responsible for this.

Yet that same week the Tokyo stock exchange fell 5 percent in one day. European stock markets slumped badly. The London Financial Times (February 13, 2016) stated:

"As the sell-off gained pace, the list of explanations for why it was happening grew longer. It was China's stagnation. It was poor global economic growth. It was low prices. It was interest rates turning negative. It was fears about banks 'capital".

Under the headline "A rout for rationality" the same "Financial Times" report quoted one senior banker saying:

"Rational people suspend rationality in fast-moving markets. There's no single cause you can point to. It's pick your poison".

Public debate on the implications of trade agreements is important but TPP has become a symbolic target for the anti-globalisation movement. A large number of society's ailments have been piled on TPP, without weighing up the real advantages that come to this country through open market access and foreign investment.

The recent added negative to the improved market access story has been falling food prices. According to "The Economist" magazine's commodity-price index
(February 20, 2016) they have tumbled 40 percent from their peak in mid-2012 The exception has been beef, which "The Economist" has put down to the lowest United States cattle inventory since the 1950s. I think there is a broader explanation which I will elaborate on later.

Here in New Zealand the greatest impact has been falling global dairy prices but lamb has also experienced downward price pressure.

Some critics of the agri-food sector are pointing to these developments as reason not to believe in the growing middle class story in China and elsewhere in Asia, and therefore future protein demand growth.

I want today to put the case that more market access is essential to the future prosperity of New Zealand hill country farming; Asia's growing demand for protein is real; and forging partnerships beyond the farm gate are necessary if increased market segmentation and consumer targeting are to achieve price premiums for hill country farming's credentials. I am deliberately staying away from the issue of the so called "social licence" to operate. Others are more expert on this thorny matter.

The debate on trade and the importance of foreign investment has not been assisted by a lack of objective data. With this is mind I recently chaired an advisory committee to the Agribusiness and Economics Research Unit at Lincoln University that has resulted in a report "The Land and the Brand". This research was jointly funded by Agmardt, Beef + Lamb New Zealand, Fonterra, Zespri, Lincoln University and ANZCO Foods (Saunders et al. 2016).

Agri-food makes up more than 70 percent of New Zealand's merchandise exports and has grown share rather than contracted, as was predicted by some leading politicians in the 1980s.

The whole economy is involved in creating this value. The last official figures available recording the growing and harvesting of the raw produce on farms, in plantations and in the sea as a proportion of Gross Domestic Product (GDP) date back to 2011/12. Then they equated to 6 percent (Figure 1).

Since nearly all this product needs processing before it can be exported or sold to domestic consumers, inputs at this stage double the sector's value to 12 percent of GDP. 


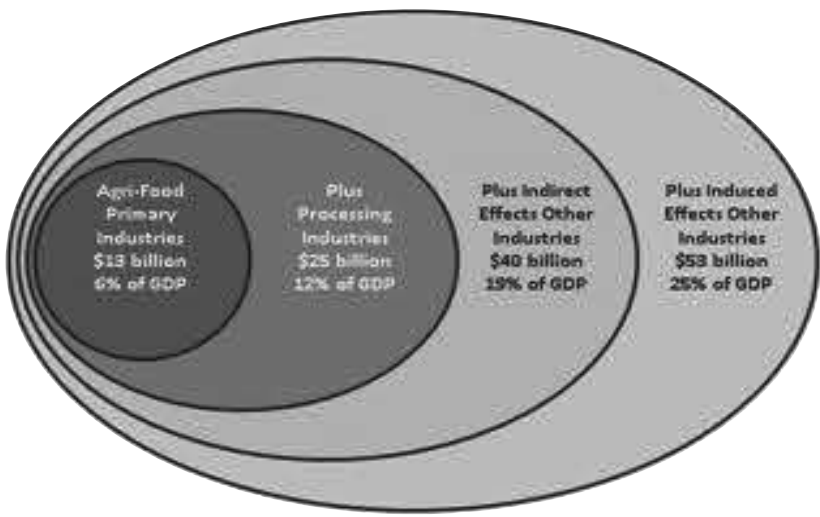

Figure 1 Contributions of the Agri-Food Sector to Gross Domestic Product, 2011-2012. (Source: Lincoln University Agribusiness and Economics Research Unit).

The primary and processing sectors in turn draw on goods and services produced across the whole economy, including transport, storage, communications and business services. Taking into account these indirect effects the total size of the agri-food sector has grown to 19 percent of GDP.

To complete the picture, the people earning these incomes, including hill country farmers, spend their money on other goods and services produced in New Zealand. If the then induced effects are counted the total contribution of the agri-food sector equates to $\$ 1$ for every $\$ 4$ spent in the economy.

We negotiate trade agreements because we seek advantage for New Zealand as a trading nation.

Our domestic market is small, our access to local capital is limited, so we need to look externally for growth and development.

This was recognised by the well-known New Zealand left commentator, Chris Trotter (Trotter 2013), who had this to say when it was announced in 2013 that Japan was joining the TPP negotiations:

"... before wealth can be redistributed, it must first be created".

New Zealand's ability to gain the most from international markets has been impeded by high trade barriers on agricultural trade. On this I quote a hero of mine, Clayton Yeutter, (Yeutter 1999) the former US Trade Representative (1985-88), who was at the centre of pressure exerted by the United States on Japan that led to the lifting of quotas on beef imports, along with some other products, and enabled ANZCO Foods to become the first foreign company to import beef into that market:

"Agricultural trade policy has long been enigmatic, often inexplicable, always exasperating, and frequently counter to the long term interest of a nation's own agriculturalists"

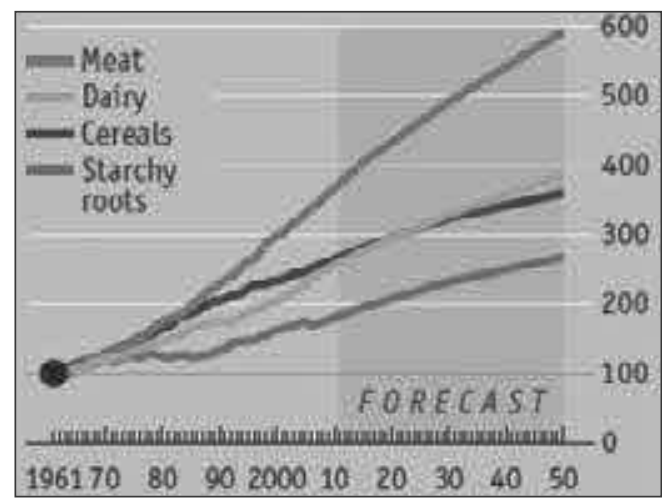

Figure 2 Global food demand, $1961=100$. (Source: FAO).

OECD data compiled since 1986 on the proportion of support to farmers in member countries by way of tariff protection, non-tariff barriers, and direct and indirect subsidies, remain high at 18 percent but are much higher in Japan and Korea at over 50 percent. Yet on average they have halved over the period due to less European Union funding but also higher global food prices (OECD 2015).

In 2009 the United Nations Food and Agriculture Organisation (FAO) published forecasts for global food demand through to 2050. Figure 2 summarises those forecasts against actual consumption since 1961. New Zealand has enjoyed a dairy boom as a result of higher demand for dairy products and improved market access. Yet the projected growth in meat demand is expected to outpace dairy. Most of the new demand will be supplied by chicken and pork but will open up unprecedented opportunities for New Zealand meat, especially beef.

Today's food security reality is that 60 percent more animal sourced foods will be needed by 2050 to satisfy growing middle class demand.

At the centre of demand growth in the immediate years ahead is China. For those who doubt the opportunities improved market access can bring to New Zealand, the rapid growth in exports following the signing of the China-New Zealand Free Trade Agreement in April 2008 has been clear for all to see.

The signing of TPP on 4 February brings New Zealand closer to a long term goal of regional integration in the Asia Pacific, with 12 of the 21 member economies of APEC on board.

TPP delivers new Free Trade Agreements (FTAs) for New Zealand with five countries (the United States, Japan, Canada, Mexico and Peru), extends our existing FTAs with Malaysia and Vietnam and updates our already highly integrated relationships with the remaining four partners - Australia, Chile, Singapore and Brunei.

Korea, Indonesia and Taiwan have all indicated 


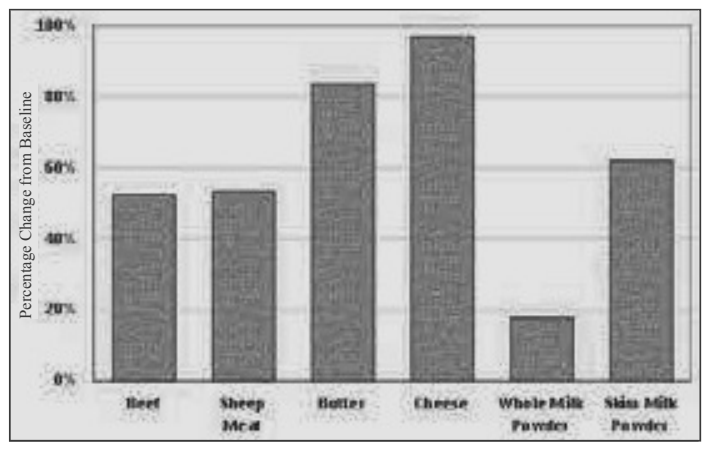

Figure 3 Increased net trade values of New Zealand exports in scenario compared with baseline (Source: Lincoln University Agribusiness and Economic Research Unit).

they wish to join TPP in the next round. How the United States learns to accommodate China is the crucial element to achieving a Free Trade Agreement of the Asia Pacific (FTAAP). If that were to occur a reinvigorated World Trade Organisation should follow.

The Agribusiness and Economics Research Unit at Lincoln University has developed a Trade and Environment model based originally on work undertaken in the United States for the Uruguay Round of the GATT trade negotiations. It can be used to analyse possible impacts of policy changes on future net trade and producer returns for 23 agri-food commodities in 23 countries or regions. "The Land and the Brand" report provides details on ten scenarios that were modelled for the project.

For illustrative purposes Figure 3 presents the net trade values to New Zealand if all barriers to trade in agri-food products were eliminated. Beef and sheepmeat could increase over 50 percent while those for dairy products could increase in the order of 20 to 100 percent.

At the New Zealand Primary Sector Bootcamp at Stanford University in 2015 it was considered an average price premium of 20 percent based on market segmentation and targeting of consumers should be an objective. Were this goal achieved the Lincoln model suggests New Zealand producer returns could increase by between 40 and 50 percent.

The total elimination of trade barriers is a lofty goal that will not be achieved in my lifetime but continuing investment by the country in this effort will provide handsome rewards and ensure the agri-food sector will continue to play a dominant role in the New Zealand economy.

To date, New Zealand has had limited success in value adding due to the country's small domestic market, ongoing trade barriers, distance from export customers, capital constraints, and entrenchment in the commodity business.

There are increasing opportunities to implement value add initiatives for meat-derived products. However, commodity demand in emerging economies can quickly push up food prices, making the implementation of a serious value add strategy by any New Zealand-based meat company an article of faith.

Important elements for success require developing a credible providence story based on deep integrity systems, which are linked to specific consumers, usually through a partnership value chain. For this to grow true partnerships will be vital between farmers, processors and other links in the value add chain.

The trader/transactional relationship that has characterised the New Zealand meat industry to date will need to change.

A win/win approach is the way forward. ANZCO Foods has been endeavouring to work in this manner for a long time.

Our partnership with the 330 Waitrose supermarket chain and the Waitrose producer club dates back 20 years. ANZCO Foods is the exclusive supplier of New Zealand lamb to Waitrose and collaborates with domestic producers in the United Kingdom, especially Welsh farmers.

The "natural beef" supply partnership with the Aleph restaurant chain in Japan, which has been much assisted by Gavin Sheath, one of this symposium's organisers, now dates back 14 years. Aleph have 338 restaurants.

South Island hill country farmers have benefitted from a longer term integrated production partnership, in Five Star Beef, which began life 27 years ago. Five Star Beef is the largest source of New Zealand chilled beef exports

ANZCO Foods is committed to growing true partnerships and has and is investing in value add initiatives, including four separate beef and co-product manufactured food sites. The jury will be out for perhaps another decade before it will be clear whether this has been a wise move. Cost focussed production driven business models could still be a major part of the agri-food sector for many years ahead.

A major influence will be the volatility of the New Zealand dollar. Tom Scott summed up the hurdles of inflation, interest rates and exchange rates in a cartoon in "The Evening Post" in 1988.

Inflation and interest rates have become lesser elements in business management since then but the burden of exchange rate movements has grown.

I want to finish by quoting Harvard Professor John Kotter, in his latest book:

"We are crossing into a territory with unpredictable turmoil and exponentially growing change - change for which we are not prepared".

I agree. All businesses in this volatile and fast 
changing age have to learn to be flexible. We need to use well the good times and hold enough in reserve for the lean times.

I am confident about the outlook for New Zealand agri-foods and hill country farming. That's why I have joined your ranks.

\section{REFERENCES/SOURCES}

Kotter, J. 2014. Accelerate: Building strategic agility for a faster-moving world. Harvard Business Review Press.

OECD. 2015. Agricultural Policy and Monitoring.

Saunders, C.; Dalziel, P.; Guenther, M.; Saunders, J.; Rutherford, P. 2016. The Land and the Brand. AERU Research Report No. 339.

Trotter, C. 2013. The Japanese connection: New Zealand, rural Japan and the TPP, October 7, 2013. Yeutter, C. 1999. The Uruguay Round and Beyond. 